\title{
Pengembangan Sistem Web Sebagai Diagnosa Dini Penyakit Alergi Kulit Dermatitis Atopik Dengan Metode Forward Chaining
}

\author{
Heny Ispur Pratiwi ${ }^{1}$, Richard Kamardi ${ }^{2}$ \\ ${ }^{1}$ Lippo Village, Karawaci, Tangerang, Banten 15811, Indonesia \\ 06hnmay@gmail.com \\ ${ }^{2}$ PT Data On, Tangerang Selatan, Banten 15413 \\ Richardkamardi10@gmail.com
}

Received 31 August 2019, Revised 11 September 2019, Accepted 25 September 2019

\begin{abstract}
The Atopic dermatitis $(A D)$ is a chronic inflammatory skin disease that arises with itchy feeling on the area. It is very common that children catch this symptoms, and they gradually get better at teens and older. But in some cases, this skin disease stays for a long time and even starts to arise at adults. The research result is a development of expert system application based on web giving users guidance or personal briefs who have experience one or more indicator patterns on Atopic Dermatitis. Forward Chaining methodology implements a pattern of algorithm development to apply for large data and hypothetic output toward single diagnose conclusion. This Web system application is used to diagnose Atopic Dermatitis, installed and served through personal computer connected to internet and stationed at a clinic or hospital lobby. Users will be guided by some rules showed by the system to observe pictures and answer given questions about signs or patterns to match what users had experienced. Those answers will be collected and processed to conclude prior diagnose to what Atopic Dermatitis type users may have and refer to doctors or experts to meet or arrange an appointment. So early stage prevention or medication could be proceeded.
\end{abstract}

Keywords: Web System Application, Atopic dermatitis, Forward Chaining

\begin{abstract}
Abstrak - Dermatitis atopik (DA) merupakan penyakit peradangan kulit kronik yang disertai rasa gatal pada kulit. Peradangan ini sering terjadi pada anak-anak usia bawah lima tahun, dan mulai membaik saat remaja, tetapi beberapa kasus penyakit tersebut bisa bertahan lama atau bahkan baru mulai terkena penyakit saat dewasa. Hasil penelitian ini merupakan pengembangan suatu aplikasi sistem pakar berbasis web guna memberi panduan atau semacam konsultasi mandiri bagi individu yang mengalami tanda dan gejala yang sama seperti panduan yang di tampilkan pada web tersebut. Metode Forward Chaining dengan pengembangan pola algoritma dipilih dengan alasan ketepatan terapan sistem yang mencakup lebih banyak luaran hipotesa dan data untuk satu kesimpulan hasil diagnosa. Aplikasi Web ini sudah bisa digunakan untuk mendiagnosa penyakit Dermatitis atopik melalui perangkat komputer yang terhubung internet tersedia di ruang tunggu klinik kesehatan atau rumah sakit. Pengguna akan dipandu oleh sistem untuk memperhatikan gambar dan menjawab pertanyaan terntang tanda dan gejala-gejala yang mungkin sedang atau pernah dialami oleh pengguna. Hasil jawaban dipakai sebagai basis sebuah diagnosa pada jenis Dermatitis Atopik yang diderita oleh pengguna dan bisa memberi rujukan untuk menemui seorang dokter ahli atau pakar tentang penyakit tersebut, sehingga tindakan pencegahan atau pengobatan secara dini bisa segera dilakukan.

Kata Kunci: Aplikasi Sistem Web, Dermatitis Atopik, Forward Chaining,
\end{abstract}

\section{PENDAHULUAN}

Penyakit eksim adalah istilah yang secara umum sebagai peradangan kulit yang terasa gatal, atau disebut dermatitis. Dermatitis atau eksim atopik adalah kondisi dimana kulit menjadi kering, pecahpecah, gatal, dan berwarna kemerahan. Dermatitis Atopik adalah salah satu bentuk eksim yang paling umum terjadi di negara beriklim tropis seperti Indonesia. Biasanya yang terjangkit penyakit ini adalah individu yang memiliki jenis kulit sensitif dan kering, namun penyebabnya bisa dari banyak hal.
Pada kasus dermatitis atopic, kondisi jenis kulit yang sensitif dan kering tersebut menjadi mudah gatal, sehingga lebih karena faktor keturunan atau genetik. Kasus Dermatitis Atopik dari faktor genetik adalah yang dominan untuk ditangani secara serius dan rutin. Adapun kasus alergi kulit yang disebabkan oleh banyak faktor lain contohnya yang disebabkan oleh unsur asing yang dianggap berbahaya oleh sistem kekebalan tubuh, sehingga jika terjangkit bisa mengakibatkan reaksi alergi. 
Beberapa tanda yang bisa dikenali di antaranya adalah kulit memerah, muncul ruam, kulit terasa gatal kemudian terlihat bengkak di area yang gatal tersebut. Bisa jadi penyebab awal adalah penggunaan produk kosmetik, produk pembersih, obat - obatan yang dioleskan di kulit, parfum (Alodokter, 2018). Dermatitis atopic pada umumnya diderita oleh anakanak di bawah lima tahun, dan biasanya disebut ruam susu yang terletak pada pipi. Bila ruam tersebut terus menerus muncul hingga si anak tumbuh dewasa, maka dapat dikatakan sebagai dermatitis atopic.

Dermatitis Atopik bisa menjadi jenis penyakit jangka panjang (kronis) dan terkadang terlihat membaik dan kembali muncul dan menjadi lebih buruk. Karena seringkali Dermatitis Atopik tidak dapat dihilangkan sepenuhnya, tetapi dapat dicegah untuk kambuh dengan perawatan dan pengawasan dokter ahli. Sisi lain cara pencegahan kambuh dermatitis atopik adalah perubahan gaya hidup dan penggunaan pelembab kulit pada area lokasi kulit yang sering terjangkit atopik.

Adapun perubahan gaya hidup contohnya dengan tidak mengkonsumsi makanan penyebab reaksi dermatitis atopik, atau menghindari zat kimia atau benda yang dapat menyebabkan ruam atopik muncul.

\section{Latar Belakang}

Seperti di uraikan pada pendahuluan, dalam kasus Dermatitis Atopik yang paling penting sebenarnya adalah pencegahan, seringkali pasien tidak dapat mengetahui dengan pasti apakah mereka atau anak anak mereka mengidap penyakit dermatitis atopik.

Selanjutnya karena seringkali Dermatitis Atopik tidak dapat dihilangkan atau disembuhkan sepenuhnya, namun dapat dicegah untuk kambuh dengan perawatan dan pengawasan dokter ahli.

Tidak ada pemeriksaan proses diagnosa yang spesifik sehingga bisa dijadikan sebagai rujukan tingkat seberapa akut jenis yang diderita individu tertentu. Sehingga petugas klinik atau rumah sakit bergantung pada pengukuran standard dan alat penganalisa untuk proses pengobatan atau terapi yang harus dilakukan. Hasil pengukuran bisa bersifat obyektif, yang biasanya dilakukan oleh seorang dokter ahli, namun bisa juga bersifat subyektif yang biasanya berdasarkan dari gejala yang di keluhkan pasien atau akibat kualitas hidup pasien tersebut.

Sehingga berdasarkan latar belakang kondisi tersebut, muncul pemikiran untuk mengembangkan sebuah sistem perangkat lunak yang dapat membantu menyediakan informasi yang diperlukan untuk pekerja di klinik kesehatan serta sebagai media konsultasi mandiri bagi individu yang mengalami gejala-gejala penyakit Dermatitis Atopik. Informasi yang disediakan sistem harus bersumber dari beberapa dokter ahli dan pengetahuan medis sehingga memberi kepercayaan terhadap pengguna seperti layaknya berkonsultasi dengan pakar dalam bidangnya.
Sistem pakar merupakan cabang dari bidang Artificial Intelligence yang dianggap sama dengan sistem berbasis pengetahuan. Bentuk luarannya adalah sebuah program Software di komputer yang dirancang untuk berperan seperti seorang pakar spesifik dalam bidang tersebut, sehingga mampu menjawab pertanyaan terhadap suatu permasalahan dan memberi solusi pada penggunanya (Adams, 2018). Salah satu pemanfaatan pengembangan sistem pakar juga dapat digunakan dalam bidang medis, seperti sistem pakar untuk deteksi dini penyakit alergi kulit (Widianto, 2018).

\section{Perumusan Masalah}

Latar belakang kondisi seperti yang di utarakan diatas memunculkan kebutuhan sebuah sistem perangkat lunak yang bisa membantu dan memandu pengguna untuk melakukan diagnosa mandiri dan merujuk secara informatif apakah gejala dan pola tanda yang dialami bisa disebut sebagai Dermatitis Atopik tingkat ringan, menengah atau tingkat yang akut.

\section{Tujuan Penelitian}

Dengan pengembangan aplikasi sistem pakar pendeteksi penyakit Alergi Kulit Dermatitis Atopik diharapkan bisa memandu pengguna melakukan diagnosa dini secara mandiri pada penyakit alergi kulit dermatitis atopik, selanjutnya bisa membantu lebih mengenali penyakit tersebut dengan cepat sehingga pencegahan atau perawatan bisa dilakukan tanpa harus bertemu dengan seorang dokter atau ahli terlebih dahulu.

\section{Sistem Penulisan}

Diawali dengan pendahuluan yang memperkenalkan topik yang dipilih oleh penulis dan inspirasi yang muncul untuk melanjutkan topik menjadi sebuah penelitian. Bagian latar belakang membentuk titik penentu menuju perumusan masalah untuk pencarian jawaban sebagai tujuan penelitian. Sedangkan sebuah metodologi diperlukan untuk mediasi pencarian jawaban tersebut yang akhirnya di kupas dalam analisa hasil, kemudian di rangkum dalam kesimpulan. Namun ada beberapa tahapan yang dilakukan penulis secara fisik untuk membentuk inspirasi yang didapat adalah memungkinkan untuk di terobos, berikut adalah beberapa tahapan tersebut:

\section{KAJIAN PUSTAKA Artificial Intelligent}

Bidang artificial intelligent (AI) lebih dari memahami, memprediksi dan memanipulasi ruang lingkup yang lebih besar, lebih rumit dari kondisi yang ada dan mencoba proses yang sama dengan membuat entitas yang cerdas yang bahkan bisa berpikir sendiri (Russel \& Norvig, 2010). Artificial Intelligent telah diterapkan pada banyak aplikasi yang sekarang ini sedang berkembang. Salah satu aplikasi tentang AI adalah menekankan kepada 
pengembangan kercerdasan program komputer. Russel dan Norvig menjelaskan definisi AI yang memiliki empat kategori, yaitu:

- Thinking Humanly; suatu usaha yang luar biasa untuk membuat bagaimana sebuah mesin dapat berpikir seperti layaknya manusia.

- Acting Humanly; sebuah seni dari membuat sebuah mesin yang menjalankan fungsi yang membutuhkan kecerdasan apabila dilaksanakan oleh manusia.

- Thinking Rationally; sebuah kajian tentang komputasi yang membuatnya menjadi mampu mempersepsikan, berpikir dan bertindak.

- Acting Rationally; adalah suatu kajian dari merancang agen (mesin) yang cerdas.

\section{Expert System (Sistem Pakar)}

Sekarang ini, Sistem Pakar telah menjadi aplikasi praktek AI secara mayoritas. Ada banyak system yang memiliki kapasitas multiguna secara operasional Dari perangkat elektronik sederhana sebuah handphone sampai robot mesin besar.

Sistem Pakar adalah program-program cerdas yang mencari solusi secara otomatis dengan mencoba untuk meniru proses-proses berpikir seorang ahli dari pengetahuan yang ditanamkan dalam sistem untuk meraih capaian pemecahan masalah (Ajlan, 2015).

\section{METODOLOGI}

Dalam perancangan sistem pakar pada penelitian ini aplikasi web yang dikembangkan adalah dengan menerapkan metode prototype. Metode prototype menuntut adanya hubungan kerja atau komunikasi intensif antara pengembang perangkat lunak dan user. Komunikasi tersebut penting bagi pengembang sehingga spesifikasi kebutuhan sistem secara rinci dirumuskan untuk solusi bagi segi teknis. Keuntungan penggunaan metode prototype adalah pengembang dapat mengetahui kesesuaian antara sistem yang akan dihasilkan dan kebutuhan pengguna tanpa harus menunggu sampai sistem diimplementasikan. Urutan cara kerja metode ini bisa dilihat pada Gambar 1.

\section{Komunikasi}

Tahapan ini dimulai dengan komunikasi, dimana penulis bertemu dengan pengguna untuk mendefinisikan keseluruhan tujuan perangkat lunak dan mengidentifikasi persyaratan apa pun yang diketahui.

\section{Perencanaan Cepat}

Pada tahap ini dilakukan desain cepat terhadap sistem. Desain cepat berfokus pada representasi aspek-aspek perangkat lunak yang akan terlihat oleh end user.

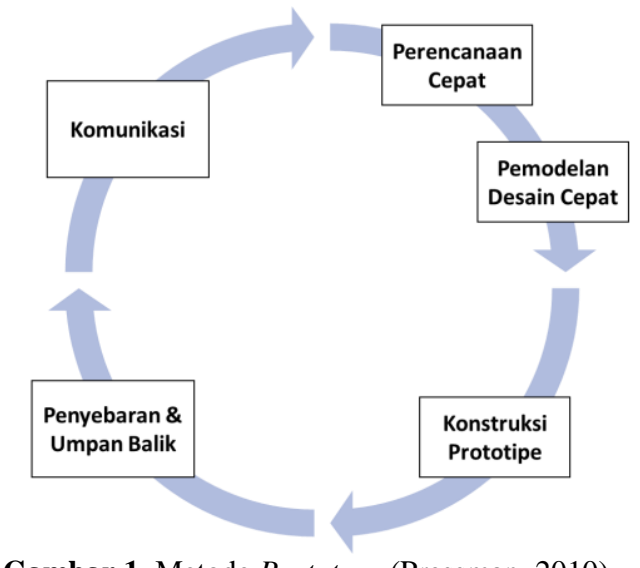

Gambar 1. Metode Prototype (Pressman, 2010)

\section{Pemodelan Desain Cepat}

Pada tahapan ini dilakukan perancangan sistem sesuai dengan kebutuhan yang telah dikomunikasikan dengan pengguna sebelumnya.

\section{Konstruksi Prototipe}

Setelah perancangan telah dibuat, maka berikutnya akan dilakukan pembuatan prototipe perangkat lunak. Pada pengembangan sistem ini akan dibuat berbasis web yang berjalan pada server lokal. Kemudian dilakukan juga pengujian terhadap sistem.

\section{Penyebaran dan Umpan Balik}

Setelah pembuatan prototipe selesai dan sistem sudah dapat berjalan sesuai dengan kebutuhan yang telah dirancangkan, maka sistem dapat diluncurkan dan digunakan oleh pengguna. Tetapi apabila sistem dirasa belum sesuai dengan rancangan yang telah dibuat maka proses akan kembali ke tahapan awal.

Sedangkan dalam perancangan panduan yang berupa pertanyaan kepada pengguna sehingga diagnosa mandiri bisa diterapkan, Forward chaining merupakan suatu metode yang pilih dengan dimulai dari mengumpulkan fakta-fakta yang ada untuk mendapatkan kesimpulan dari fakta tersebut (Akil, 2017). Proses penalaran fakta-fakta untuk menuju pada suatu tujuan. Metode ini juga menggunakan aturan dimana premis menjadi sebuah kesimpulan (Supartini, 2016).

Lebih jelasnya adalah metode Forward Chaining adalah tehnik pencarian dimulai pada fakta yang didapatkan, kemudian melakukan perbandingan fakta-fakta tersebut secara kondisi penentu IF dari rules IF -THEN (Sutojo, Mulyanto \& Suhartono, 2011). Bila hasil perbandingan fakta ternyata cocok kondisi penentu IF, maka rule tersebut akan dieksekusi. Dalam situasi terdapat rule yang dieksekusi, maka didapatkan satu fakta baru yang lain (yaitu THEN) bisa ditambahkan sebagai data pada database.

Adapun metode inference yang menerapkan metode forward chaining melakukan penelusuran yang dimulai dari anteseden atau isu yang dihadapi. Pemrosesan dilakukan sebagai serangkaian konsekuensi berupa irisan isu atau permasalahan 
dengan penyebab dan solusinya (Mohammad \& Bani, 2015). Metode inference forward chaining atau dalam istilah lainnya adalah data driven, dengan kesamaan proses yang dimulai dengan fakta-fakta dan menelusuri aturan-aturan yang ditetapkan sampai diperoleh kesimpulan. Diagram alur pada Gambar 2 dan uraiannya bisa lebih memberikan penjelasan proses sistem forward chaining.

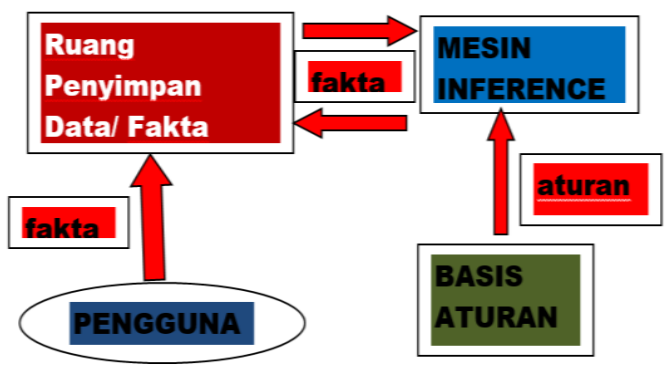

Gambar 2. Model sistem forward chaining (Chakraborty, 2015)

Pada Gambar 2 diatas Chakraborty mendeskripsikan alur proses sistem forward chaining, yaitu diawali oleh pengguna atau user yang memberi fakta-fakta yang tersimpan dalam ruang penyimpanan data atau working memory, lalu fakta-fakta tersebut terkomunikasikan dan terproses dua arah balik terhadap Inference Engine yang cara kerjanya diatur oleh Rule Base yang responsif terhadap kondisi-aksi yang berinteraksi ketika fakta tertentu muncul dalam working memory. Tindakan respon biasanya berupa pencatatan serta penambahan dan penghapusan fakta dari working memory. Singkatnya algoritma yang diterapkan secara adalah seperti berikut:

Pengulangan:

- Kumpulkan aturan yang kondisinya sesuai dengan fakta yang ada didalam memori kerja;

- Lakukan aksi sesuai aturan tersebut (menambahkan / menhapus fakta di memori kerja);

- Lanjutkan sampai masalah terselesaikan atau tidak ada lagi kondisi yang sesuai.

\section{HASIL DAN ANALISIS}

Pengguna sistem Web diagnosa dini penyakit alergi kulit dematitis atopik yang dirancang dalam penelitian ini adalah pasien dan admin sebagai end user. Sistem ini terbagi dalam dua bagian yaitu front end dan back end, dimana front end merupakan halaman yang ditujukan kepada pengguna dan back end halaman yang hanya dapat digunakan oleh admin. Pada bagian front end, pengguna dapat melakukan dan melihat informasi penyakit dermatitis atopik, sedangkan bantuan penggunaan program, serta melakukan periksadiini penyakit dermatitis atopik.

\section{Implementasi Front End}

Gambar 3 berikut adalah tampilan layar front end yang dirancang.

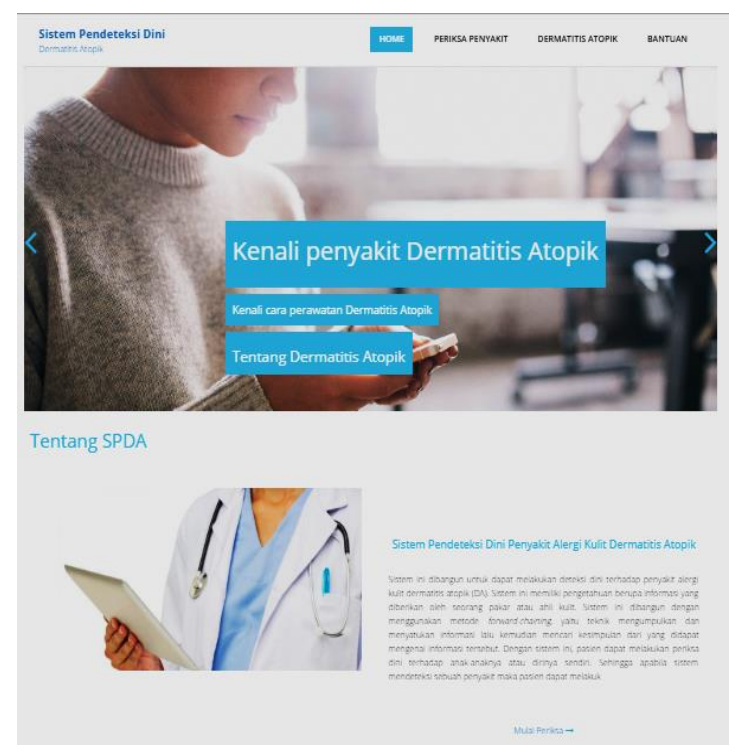

Gambar 3. Halaman menu home pasien

Tampilan halaman menu periksa penyakit pada Gambar 4, muncul setelah pengguna mengakses dari baris menu halaman utama bagian atas pada Gambar 3 , adalah data atau fakta yang sudah dilakukan oleh pengguna dan tersimpan dalam ruang penyimpanan data. Tampilan memunculkan data pasien atau pengguna dan aktifitas konsultasi yang sudah atau pernah dilakukan.

\section{Halaman Menu Periksa Penyakit}

Tampilan halaman menu Dermatitis Atopik pada Gambar 5, muncul setelah pengguna mengakses dari baris menu halaman utama bagian atas pada Gambar 3 , adalah data atau fakta yang sudah dilakukan oleh admin dan tersimpan dalam ruang penyimpanan data. Tampilan memunculkan deskripsi informasi secara visual penyakit dermatitis atopik.

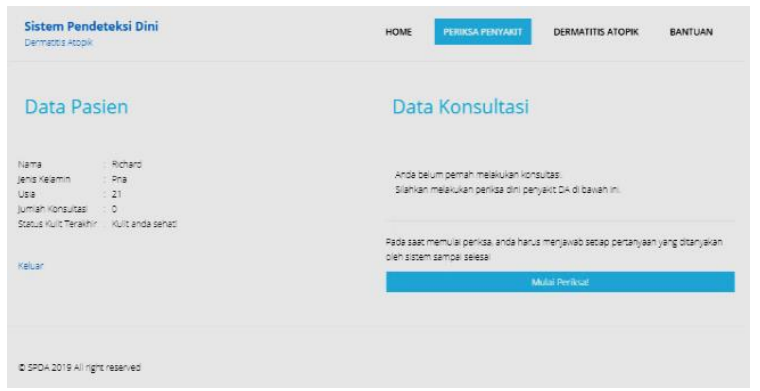

Gambar 4. Halaman menu periksa penyakit

\section{Halaman Menu Dermatitis Atopik}

Tampilan halaman menu bantuan pada Gambar 6, muncul setelah pengguna mengakses dari baris menu halaman utama bagian atas pada Gambar 3, adalah data atau fakta yang sudah dilakukan oleh admin dan tersimpan dalam ruang penyimpanan data. Tampilan memunculkan akses bantuan kepada pasien atau pengguna. 


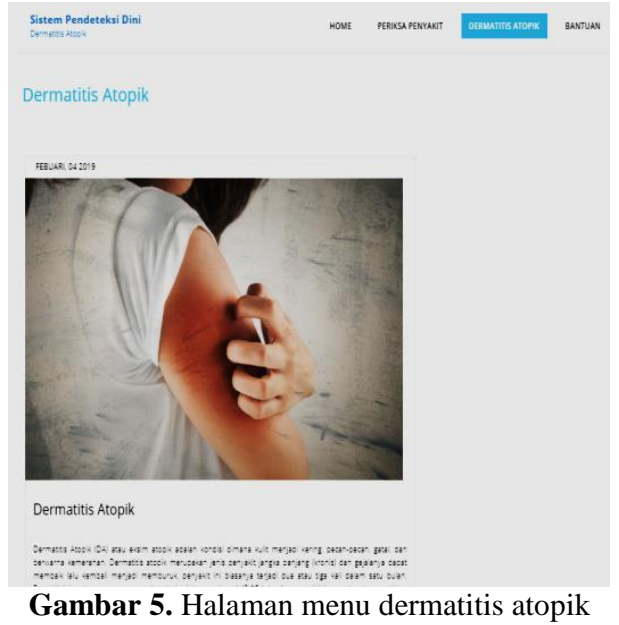

3. Halaman Menu Bantuan

Tampilan halaman konsultasi pada Gambar 7, muncul setelah pengguna mengakses salah satu dari pilihan yang muncul pada menu bantuan pada Gambar 6 , adalah data atau fakta yang sudah dilakukan oleh admin dan tersimpan dalam ruang penyimpanan data. Tampilan memunculkan akses konsultasi kepada pasien atau pengguna dengan menjawab pertanyaan yang disediakan. Pengguna akan terus dipandu oleh beberapa pertanyaan berikutnya apapun pilihan jawaban yang diberikan.

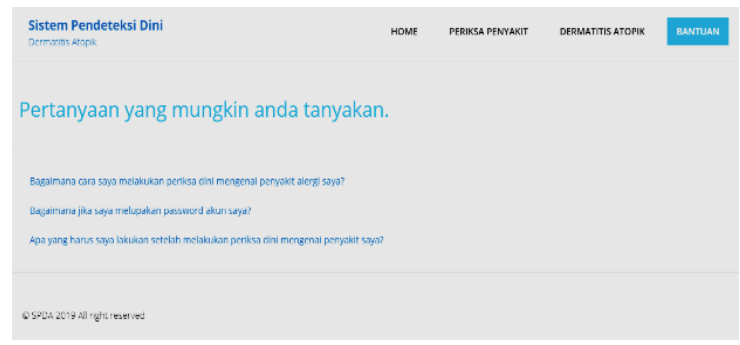

Gambar 6. Halaman menu bantuan

\section{Halaman Konsultasi}

Tampilan halaman konsultasi pada Gambar 8, muncul setelah pengguna mengakses salah satu dari pilihan yang muncul pada menu konsultasi pada Gambar 7, adalah data atau fakta yang sudah dilakukan oleh admin dan tersimpan dalam ruang penyimpanan data.

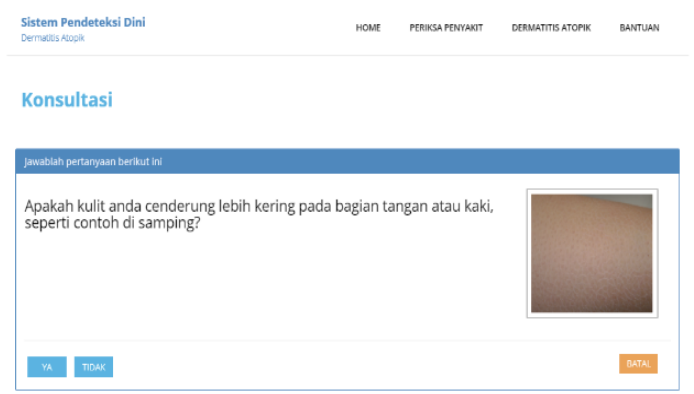

Gambar 7. Halaman konsultasi

Setelah pengguna selesai menjawab semua pertanyaan dalam menu konsultasi, sistem akan memberi kesimpulan apakah pengguna bisa dikatakan terjangkit Dermatitis Atopik serta melengkapi informasi tentang tingkat ke-akut-an sehingga referensi untuk pemeriksaan lebih lanjut dimunculkan.

5. Halaman Hasil Konsultasi

Sistem pembangunan web juga memuat hasil konsultasi seperti gambar berikut.

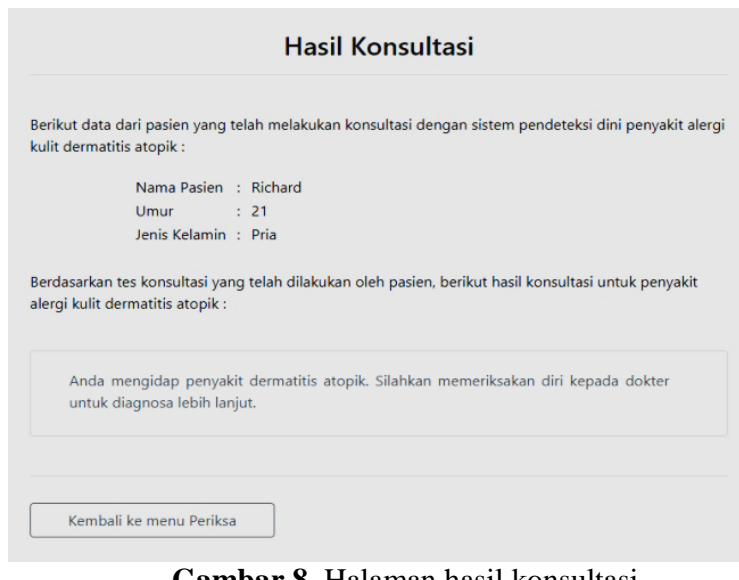

\section{Implementasi Back End}

1. Halaman Hasil Konsultasi

Pada bagian back end, admin dapat melihat semua hasil konsultasi yang pernah dilakukan oleh salah satu atau semua pengguna, tampilan untuk ini ada di Gambar 9.

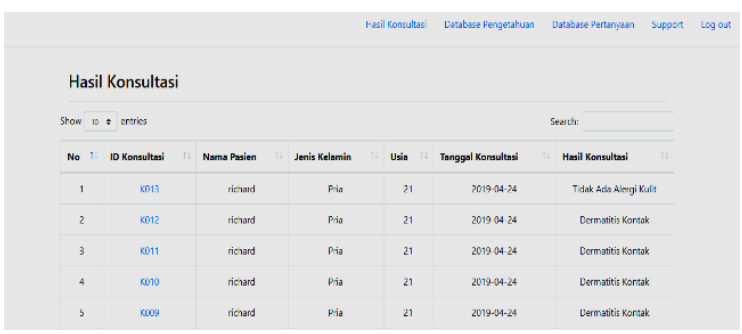

Gambar 9. Halaman hasil konsultasi

\section{Halaman Database Pertanyaan}

Selain itu admin juga dapat menambahkan pertanyaan baru atau mengedit pertanyaan yang sudah ada di halaman menu Database Pertanyaan, tampilan untuk ini ada pada Gambar 10.

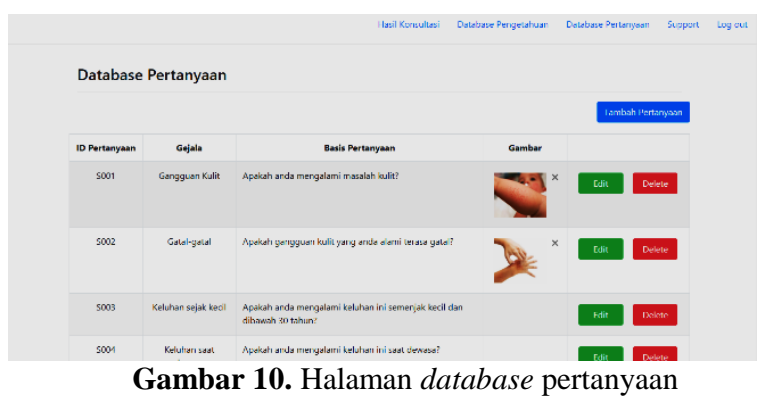


3. Halaman database pengetahuan

Admin juga dapat mengedit pengetahuan yang mengatur alur forward chanining pada pertanyaan di menu Database Pengetahuan, tampilan untuk ini ada pada Gambar 11.

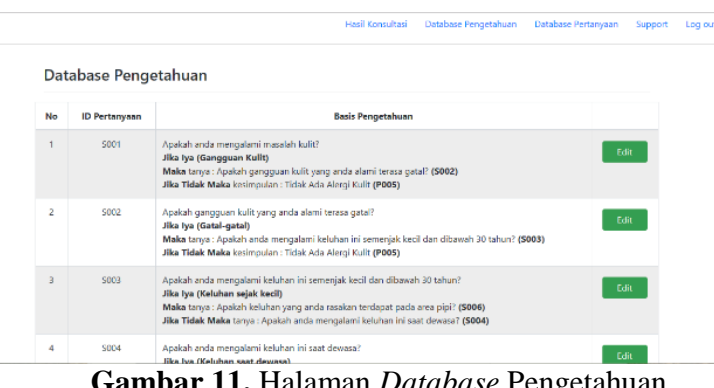

4. Halaman Support

Selain itu terdapat juga menu support yang disediakan untuk memberi petunjuk kepada admin, tampilan untuk ini ada pada Gambar 12.

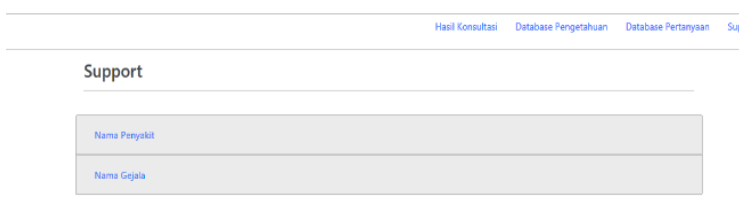

Gambar 12. Halaman Support

\section{Pengujian Inference engine}

Pengujian mesin inferensi (Inference engine) untuk menguji setiap aturan (rule) yang telah dibuat terhadap sistem ini. Terdapat tigapuluh dua atau 32 aturan yang digunakan dalam sistem ini. Berdasarkan pengujian mesin inferensi pada tabel 2 , terdapat lima parameter gejala yang digunakan dalam aturan berupa tiga gejala mayor (gatal-gatal, predileksi DA, dan kronis) dan dua gejala minor (riwayat penyakit, xerosis, pityriasis alba, dennie morgan, dan rentan infeksi kulit).

Nilai nol (0) pada tabel tersebut dapat diartikan sebagai "tidak ada gejala", dan nilai satu (1) yang berarti "ada gejala". Aturan di atas dapat didefinisikan sebagai berikut :

- Rule 1:

$$
\begin{aligned}
& \text { IF } \\
& \text { THEN }
\end{aligned}
$$

persentase terkena DA RENDAH.

- Rule 2 :

$$
\text { IF }
$$

THEN

$$
\begin{aligned}
& \text { gejala Mayor }>=2 \\
& \text { AND } \\
& \text { gejala Minor }>=1
\end{aligned}
$$

persentase terkena DA MENENGAH.

- Rule 3 :

$$
\text { IF }
$$

$$
\text { gejala Mayor }>=2
$$

\author{
THEN \\ gejala minor $>=2$ \\ persentase terkena DA TINGGI.
}

- Rule 4 :

IF

gejala Mayor $>=3$

AND

THEN

gejala minor $==0$

persentase terkena DA MENENGAH.

- Rule 5 :

IF

gejala Mayor $>=3$

AND

THEN

gejala minor $>=0$

persentase terkena DA TINGGI

Seperti yang disebutkan pada bagian pengujian Inference engine, tabel 1 berikut terdapat label ' $\mathrm{M}$ ' bisa diartikan sebagai "Gejala Mayor" dan ' $\mathrm{m}$ ' bisa diartikan sebagai "Gejala Minor". Aturan-aturan yang tertera di atas hanya berlaku apabila pengguna mendapat gejala yang mengarah kepada gejala penyakit dermatitis atopik.

Tabel 1. Pengujian mesin inferensi

\begin{tabular}{lllllll}
\hline No. & M1 & M2 & M3 & $\mathrm{m} 1$ & $\mathrm{~m} 2$ & $\begin{array}{c}\text { Kemungkinan } \\
\text { Derma. Atopik }\end{array}$ \\
\hline 1 & 0 & 0 & 0 & 0 & 0 & Rendah \\
2 & 0 & 0 & 0 & 0 & 1 & Rendah \\
3 & 0 & 0 & 0 & 1 & 0 & Rendah \\
4 & 0 & 0 & 0 & 1 & 1 & Rendah \\
5 & 0 & 0 & 1 & 0 & 0 & Rendah \\
6 & 0 & 0 & 1 & 0 & 1 & Rendah \\
7 & 0 & 0 & 1 & 1 & 0 & Rendah \\
8 & 0 & 0 & 1 & 1 & 1 & Rendah \\
9 & 0 & 1 & 0 & 0 & 0 & Rendah \\
10 & 0 & 1 & 0 & 0 & 1 & Rendah \\
11 & 0 & 1 & 0 & 1 & 0 & Rendah \\
12 & 0 & 1 & 0 & 1 & 1 & Rendah \\
13 & 0 & 1 & 1 & 0 & 0 & Rendah \\
14 & 0 & 1 & 1 & 0 & 1 & Menengah \\
15 & 0 & 1 & 1 & 1 & 0 & Menengah \\
16 & 0 & 1 & 1 & 1 & 1 & Tinggi \\
17 & 1 & 0 & 0 & 0 & 0 & Rendah \\
18 & 1 & 0 & 0 & 0 & 1 & Rendah \\
19 & 1 & 0 & 0 & 1 & 0 & Rendah \\
20 & 1 & 0 & 0 & 1 & 1 & Rendah \\
21 & 1 & 0 & 1 & 0 & 0 & Rendah \\
22 & 1 & 0 & 1 & 0 & 1 & Menengah \\
23 & 1 & 0 & 1 & 1 & 0 & Menengah \\
24 & 1 & 0 & 1 & 1 & 1 & Tinggi \\
25 & 1 & 1 & 0 & 0 & 0 & Rendah \\
26 & 1 & 1 & 0 & 0 & 1 & Menengah \\
27 & 1 & 1 & 0 & 1 & 0 & Menengah \\
28 & 1 & 1 & 0 & 1 & 1 & Tinggi \\
29 & 1 & 1 & 1 & 0 & 0 & Menengah \\
30 & 1 & 1 & 1 & 0 & 1 & Tinggi \\
31 & 1 & 1 & 1 & 1 & 0 & Tinggi \\
32 & 1 & 1 & 1 & 1 & 1 & Tinggi \\
\hline & & & & & & \\
\hline
\end{tabular}




\section{Pengujian White Box}

Berikut merupakan pengujian white box yang telah dilakuka pada sistem ini :

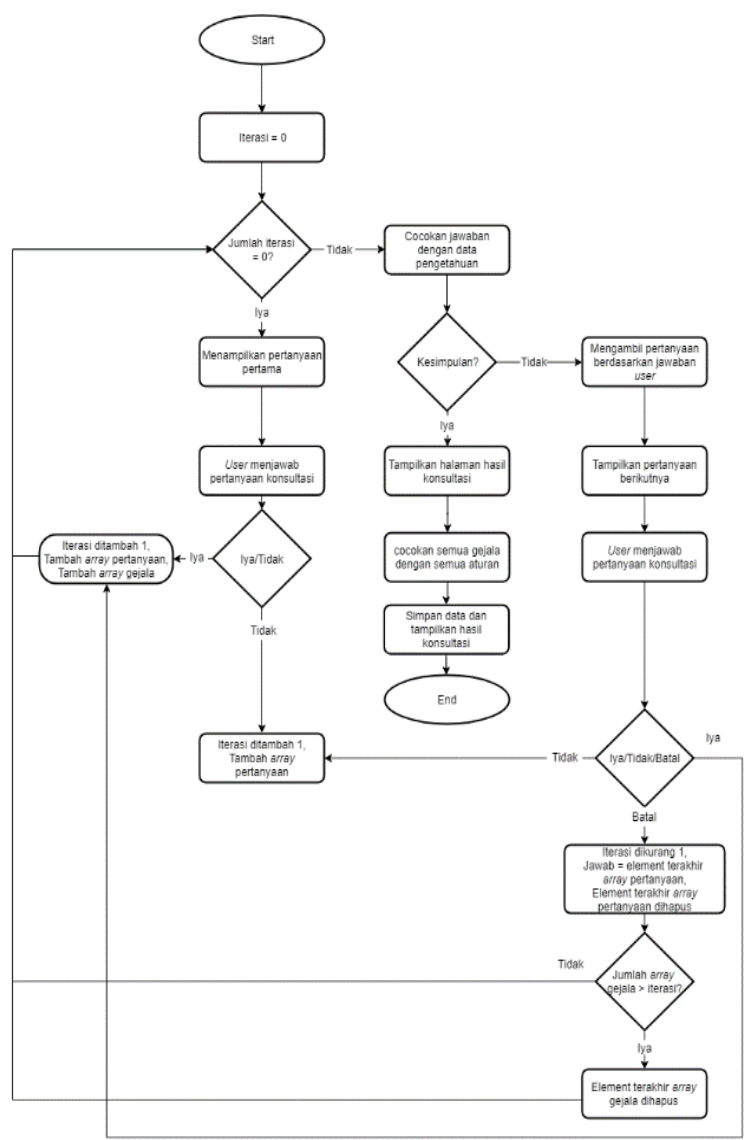

Gambar 13. Flowchart dermatitis atopik

\section{Pengujian secara Flowgraph}

Diketahui node dan edge dari flowgraph pada gambar 13 dengan penjelasan sebagai berikut: Node: 18 Edge : 26

Untuk dapat menghitung hasil cyclomatic complexity pada flowgraph tersebut, dapat menggunakan rumus seperti berikut :

$$
\begin{aligned}
\mathrm{V}(\mathrm{G}) & =\mathrm{E}-\mathrm{N}+2 \\
& =26-18+2 \\
& =10
\end{aligned}
$$

Hasil independent path pada flowgraph dibawah ini dapat dijabarkan sebagai berikut :

Path 1 : 1-2-3-4-5-6-7-3-9-10-18-19-20

Path 2 : 1-2-3-4-5-6-8-3-9-10-18-19-20

Path 3 : 1-2-3-4-5-6-7-3-9-10-11-12-13-14-7$3-9-10-18-19-20$

Path 4 : 1-2-3-4-5-6-7-3-9-10-11-12-13-14-8$3-9-10-18-19-20$

Path 5 : 1-2-3-4-5-6-7-3-9-10-11-12-13-14-15$16-3-9-10-18-19-20$

Path 6 : 1-2-3-4-5-6-7-3-9-10-11-12-13-14-15$16-17-3-9-10-18-19-20$

Path 7 : 1-2-3-4-5-6-7-3-9-10-11-12-13-14-7$3-9-10-11-\ldots-20$

Path 8 : 1-2-3-4-5-6-7-3-9-10-11-12-13-14-8$3-9-10-11-\ldots-20$
Path 9 : 1-2-3-4-5-6-7-3-9-10-11-12-13-14-15$16-3-9-10-\ldots-20$

Path 10 : 1-2-3-4-5-6-7-3-9-10-11-12-13-14$15-16-17-3-9-10-11-\ldots-20$

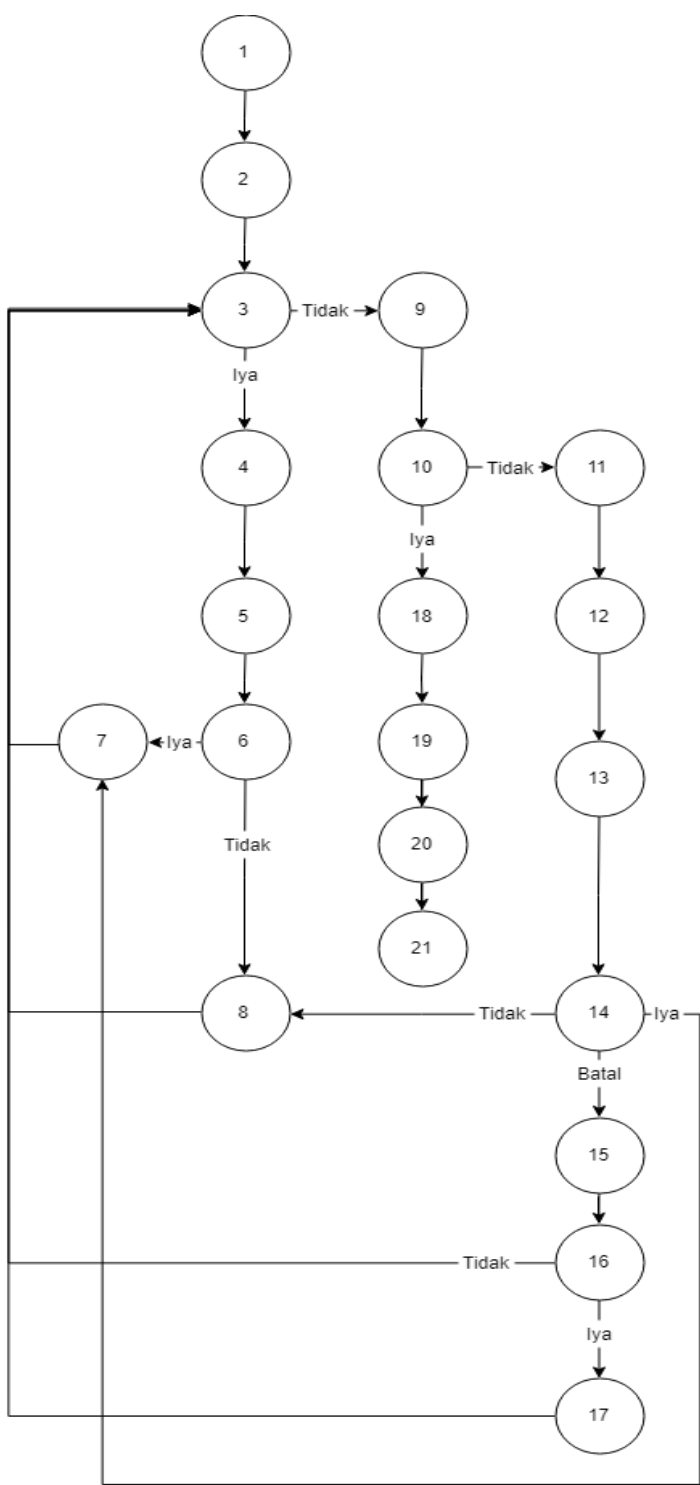

Gambar 14. Flowgraph sistem diagnosa dini dermatitis atopik

\section{KESIMPULAN}

Dengan sistem yang sudah dibangun, pengguna bisa terbantu dan dipandu untuk melakukan diagnosa dini penyakit kulit dermatitis atopik secara mandiri. Keunggulan diagnosa mandiri dengan metode forward chaining merujuk pada setiap jawaban yang diberikan kepada pengguna dari pertanyaan yang ada dalam sistem, jawaban yang dipilih merujuk pada pertanyaan berikutnya dan seterusnya berkelanjutan, sampai sebuah kesimpulan didapatkan dan ditampilkan pada bagian hasil konsultasi.

Sistem yang dibangun ini juga dapat membantu pengguna untuk lebih memahami mengenai penyakit alergi kulit dermatitis atopik sehingga pengguna bisa 
melakukan pencegahan atau perawatan untuk menjaga kesehatan kulit.

Teknologi image processing bisa menjadi salah satu pilihan topik untuk pengembangan kelanjutan sistem ini. Fitur Image Processing akan melengkapi kapasitas sistem yang ada dengan kemampuan untuk mencocokan gejala alergi kulit pada pasien dengan kriteria spesifik untuk hasil diagnosa yang lebih akurat. Adapun penggunaan metode penjumlahan berbobot seperti metode SAW (Simple Additive Weighting) bisa sebagai pilihan yang lain dalam pengembangan lanjut sistem ini menuju peningkatan efektifitas dan tingkat keakuratan hasil luaran.

\section{UCAPAN TERIMA KASIH}

Tulisan ini adalah juga hasil kerjasama dan bantuan dari pihak Universitas Pembangunan Jaya Tangerang, penulis dalam hal ini mengucapkan terimakasih, semoga bisa menginspirasi banyak pembaca.

\section{DAFTAR PUSTAKA}

Adams, M. J. (2018). Expert system in Encyclopedia of analytical science. Second Edition. Melbourne, Australia.

Ajlan, A. (2015). The comparison between forward and backward chaining. International Journal of Machine Learning and Computing, 106-113.

Akil, I. (2017). Analisa efektifitas metode forward chaining dan backward chaining pada sistem pakar. Jurnal Pilar Nusa Mandiri, 13(1), 3542.

Alodokter (2018). Mengetahui penyebab dan cara menangani alergi kulit. https://www.alodokter.com/MengetahuiPenyebab-dan-Cara-Menangani-Alergi-Kulit [19 Oktober 2018].

Chakraborty, R. C. (2015). Knowledge Representation: AI Course Lecture.

Falatehan, A. I., Hidayat, N. \& Brata, K. C. (2018). Sistem pakar diagnosis penyakit hati menggunakan metode fuzzy tsukamoto berbasis android. Jurnal Pengembangan Teknologi Informasi dan Ilmu Komputer, 2(8), 2372-2381.

Pressman, S. R. (2010). Software engineering: a practitioners approach. Seventh Edition, The McGraw Hill Companies.

Russel, S. \& Norvig, P. (2010). Artificial intelligent a modern approach. Third Edition. New Jersey: Pearson Education.

Mohammad, S. N. \& Bani, A. Y. H. (2015). Forwardchaining approach to expert system for machine maintenance. Proceedings of Mechanical Engineering Day.

Supartini, W. \& Hindarto, H. (2016). Sistem pakar berbasis web dengan metode forward chaining dalam mendiagnosa dini penyakit tuberkulosis Di Jawa Timur. Kinetik: Game Technology, Information System, Computer
Sutojo, Mulyanto, Suhartono, (2011). Kecerdasan buatan, Yogyakarta: Andi. 